Sociologia

\section{Pesquisadores investigam 0 grupo Anonymous, os ativistas hackers do novo século}

Muito falado desde que promoveu ataques de negação de serviço (em que uma ação coletiva provoca a queda de um site) a grandes companhias financeiras como a Mastercard e a Visa, o grupo Anonymous se notabiliza por ser difícil de ser classificado ou rotulado. Buscando entender esse grupo de forma ampla, mas também comparativamente com sua versão brasileira, os pesquisadores Sergio Amadeu, Murilo Machado e Rodrigo Savazoni, da Universidade Federal do ABC, escreveram o artigo "As múltiplas faces dos Anonymous: ativismo político nas redes digitais", apresentado na $36^{a}$ reunião da Associação Nacional de Pós-Graduação e Pesquisa em Ciências Sociais (Anpocs). Segundo eles, os ativistas brasileiros que se reivindicam como Anonymous são mais diversos ideologicamente e têm maior dificuldade em organizar açóes conjuntas, enquanto os norte-americanos têm maior capacidade de ação política e realizam açóes visando principalmente o governo federal dos EUA e a indústria do copyright (estúdios, gravadoras, editoras). Por serem perseguidos pelo governo dos Estados Unidos, que os classifica como grupo terrorista, os norte-americanos são também mais preocupados com questóes de segurança, com garantir tecnologicamente seu anonimato.

A pesquisa que deu base ao artigo investigou duas datas específicas: a véspera de aprovação dos projetos Sopa e Pipa, dia 17 de janeiro, e o dia seguinte ao fechamento do site Megaupload, dia 20 do mesmo mês. Sopa (Stop Online Piracy Act) e Pipa (Protect IP Act) foram propostas legislativas de enrijecimento da punição a violaçóes de direito autoral apresentadas ao Congresso dos EUA. Vistas pelos ativistas como limitadoras das liberdades e dos direitos de expressão, enfrentaram um duro protesto na rede, em que diversos sites importantes ficaram fora do ar em um movimento coordenado. Já o Megaupload era um site de compartilhamento de arquivos que foi fechado sob acusação de violaçãa de direitos autorais. O encerramento das atividades do Megaupload foi acompanhado por uma ação espetacular de prisão de seu fundador, Kim Dotcom, residente na Nova Zelândia, que foi contestada em sua legalidade por muitos juristas. Para Amadeu, ela aconteceu para satisfazer os interesses da indústria, já que o Sopa foi retirado após a oposição popular.
Os pesquisadores investigaram a ação de quatro perfis de Twitter do grupo, dois dos EUA, @YourAnonNews e @anonops, e dois do Brasil, @AnonBRNews e @PlanoAnonBr. A análise foi qualitativa, os autores buscaram "entender o significado político, ideológico e cultural do que é dito e não dito, comparando possíveis diferenças de visão, discurso e postura diante dos mesmo fatos que animaram intensamente as redes". Os perfis investigados são os que reúnem maior número de seguidores nos Estados Unidos e no Brasil. A manifestação do grupo chegou a derrubar os sites da Casa Branca e do FBI em janeiro deste ano.

"O ativismo político em rede encontra no hacktivismo uma de suas mais marcantes expressões”, afirmam os autores. Eles entendem os hacktivistas como um novo tipo de hackers, "não apenas peritos em computação, mas indivíduos motivados por preocupaçóes éticas e que creem que seus atos devem ser considerados uma forma legítima de desobediência civil". Eles apontam que o ativismo político em rede encontra no hacktivismo uma de suas mais marcantes expressóes. "Compreendê-lo é fundamental para lançar interpretaçôes aos novos movimentos sociais que ganharam força na aurora do século XXI", alertam. 